\title{
LIMITING JUDICIAL INTERVENTION IN ONGOING ADMINISTRATIVE PROGEEDINGS
}

As administrative agencies have grown in number and complexity, so have the problems of articulating the point at which federal courts are empowered or required to intervene in administrative agency proceedings. This Comment focuses upon one device -the doctrine of exhaustion of administrative remedies-that seeks to define the respective roles of the courts and the agencies in the administrative process and to ease the tensions between these two centers of authority. The exhaustion requirement, generally stated, prevents a party from obtaining judicial relief from agency action until all the prescribed administrative remedies are first resorted to. ${ }^{1}$ Among other things, this discretionary and self-imposed rule prevents the courts, by premature intervention, from hampering the efficiency of the administrative process. $^{2}$ The courts, however, have introduced several exceptions to the exhaustion requirement that allow them to intervene in ongoing agency proceedings under certain circumstances.

This Comment examines the exhaustion doctrine in light of its fundamental purposes and concludes that the doctrine fails to achieve those goals. Owing to its highly discretionary and amorphous nature, the exhaustion requirement not only allows courts to interfere with agency action on an ad hoc basis ${ }^{3}$-undermining administrative authority-but more importantly, it encourages disgruntled parties to circumvent established agency procedures through judicial intervention. In either case, exhaustion, as it has been developed, operates to erode the congressionally mandated administrative process.

After describing the contours of the exhaustion doctrine and its exceptions in part $I$, the Comment will go on, in part II, to dis-

1 See generally $\mathrm{K}$. Davis, Administrative Law of the Seventres $\$ \$ 20.01-.08$ (1976); L. Jaffe, Judicial Control of Administrative Action 424-58 (1965); Berger, Exhaustion of Administrative Remedies, 48 YALE L.J. 981 (1939); Fuchs, Prerequisites to Judicial Review of Administrative Agency Action, $5 \mathrm{I}$ IND. L.J. 859 (1976); Jaffe, The Exhaustion of Administrative Remedies, 12 Bufralo L. Rev. 327 (1963); Zacharias, Exhaustion of Administrative Remedies-A Synthesis of the Law and a Proposed Statute for Federal Prison Cases, 4 N. ENG. J. Pruson L. 5 (1977); Comment, Exhaustion of Administrative Remedies, 39 CoRNell L.Q. 273 (1954); Note, The Doctrine of Exhaustion of Administrative Remedies, 18 WAYNE L. REv. 1403 (1972).

2 McKart v. United States, 395 U.S. 185, 193 (1969).

3 5 B. Mezines, J. Stein \& J. Gruff, Administratrve Law $\$ 49.02$ (1980); see notes 16-62 infra \& accompanying text. 
cuss the use of the "final agency action" limitation on judicial review of agency proceedings found in section 10(c) of the Admin. istrative Procedure Act (APA). ${ }^{4}$ The Comment evaluates two judicial approaches to finality-those of Judges Friendly and Leventhal-concluding that the utility of section 10 (c) for preserving the integrity of the administrative process turns upon interpreting finality as a limit on federal court jurisdiction to review ongoing agency proceedings. Part III continues the discussion of finality by offering a definition of final agency action that attempts to further the underlying purpose of the exhaustion rule. This definition isolates two indicia of final agency action-directness and externality of effects-that, when present, will satisfy the jurisdictional prerequisite to judicial intervention. The Comment also proposes to replace the few necessary exceptions to the exhaustion doctrine with the traditionally narrow mandamus jurisdiction of the federal courts.

A jurisdictional definition of finality, such as is proposed by this Comment, coupled with the use of the federal mandamus power, can avoid unwarranted disruptions of ongoing administrative proceedings by providing the courts with a clear and precise standard for determining when intervention is appropriate. The theory advocated has the additional advantage of discouraging parties before agencies from attempting to skirt proper agency procedures, thereby preserving the effectiveness and independence of administrative decisionmaking.

\section{The Exhaustion Doctrine}

\section{A. Definition and Purpose}

The doctrine of exhaustion of administrative remedies is the universally recognized bar to a petitioner seeking equitable relief from agency action prior to the completion of administrative proceedings. ${ }^{5}$ This "long-settled rule of judicial administration" pro. vides that "no one is entitled to judicial relief from a supposed or threatened injury until the prescribed administrative remedy has been exhausted." " Due largely to its genesis as an equitable

45 U.S.C. $\$ 704$ (1976). See text accompanying note 65 infra.

See note I supra \& accompanying text.

6 Myers v. Bethlehem Shipbuilding Corp., 303 U.S. 41, 50-51 (1938) (footnote omitted). The "judicial relief" spoken of here refers primarily to suits for injunctive relief in federal district court. 
principle, ${ }^{7}$ exercise of the exhaustion rule is generally viewed as a matter within a court's discretion and does not bear upon the court's jurisdiction. ${ }^{8}$

The courts have fashioned the exhaustion requirement to fulfill several purposes, all of which are related to the fundamental notion that administrative agencies are entitled to a certain degree of judicial deference. In McKart $v$. United States, for example, the Supreme Court stated that "[a] primary purpose [of the exhaustion doctrine] is . . the avoidance of premature interruption of the administrative process." 9 Principal among the reasons that the Court gave for wanting to avoid such an "interruption" were to let the agency develop a factual record; to allow the agency the first chance to exercise its discretion and/or expertise; and to avoid hampering the efficiency of the administrative process through piecemeal judicial review. ${ }^{10}$ Each of these reasons might be suf-

7 The exhaustion rule evolved as a corollary to the principle that equity would not intervene when there existed an adequate remedy at law. See Berger, supra note 1, at 983; Comment, Exhaustion of Administrative Remedies, 39 Cornelu L.Q. 273, 274-75 (1954). Cf. Fairchild, Arabatzis \& Smith, Inc. v. Sackheim, 451 F. Supp. 1181, 1184 (S.D.N.Y. 1978) (the exhaustion doctrine has been interpreted as "reflecting equity"s reluctance to intervene when the law provides an adequate remedy").

8 Aircraft \& Diesel Equip. Corp. v. Hirsh, 331 U.S. 752, 764 (1947); South Dakota v. Andrus, 614 F.2d 1190, 1192 n.I (8th Cir. 1980); Montgomery v. Rumsfield, 572 F.2d 250, 254 (9th Cir. 1978); Dry Creek Lodge v. United States, 515 F.2d 926, 933 n.7 (10th Cir. 1975); United States ex rel. Tobias v. Laird, 413 F.2d 936, 939 (4th Cir. 1969); Tumer v. Callaway, 371 F. Supp. 188, 192 (D.D.C. 1974); Patterson v. Stancliff, 330 F. Supp. 110, 112-13 (D. Va. 1971).

That the exhaustion doctrine operates solely upon a discretionary level appears to be accepted by most American courts. Until recently, however, the Ninth Circuit regarded the doctrine as a limit on the jurisdiction of the court. See Hills v. Eisenhart, 256 F.2d 609, 611 (9th Cir. 1958); Herriges v. United States, 314 F. Supp. 1352, 1354 (D. Mont. 1970); United States v. Bradt, 280 F. Supp. 858, 859 (C.D. Cal. 1968). That approach has since been modified, and a distinction is now drawn by the Ninth Circuit between cases in which the exhaustion requirement is statutorily mandated and cases in which no such mandate applies. In the latter category, the jurisdictional view has been rejected. See Eluska v. Andrus, 587 F.2d 996, 999 (9th Cir. 1978); Montgomery v. Rumsfield, 572 F.2d at 252-53.

9 McKart v. United States, 395 U.S. 185, 193 (1969). See also Weinberger v. Salfi, 422 U.S. 749, 765 (1975); First Jersey Sec., Inc. v. Bergen, 605 F.2d 690, 695 (3d Cir. 1979), cert. denied, 100 S. Ct. 1020 (1980); Sterling Drug, Inc. v. FTC, 450 F.2d 698, 710 (D.C. Cir. 1971); K. Davis, Administrative Law Text $\$ 20.02$, at 385-86 (3d ed. 1972); 5 B. Mezines, J. Stein \& J. Gruff, AdministraTIVE LAW $\$ 49.01$ (1980).

10395 U.S. at 194. See also Parisi v. Davidson, 405 U.S. 34, 37 (1972) (stating that the doctrine's "basic purpose ... is to allow an administrative agency to perform functions within its special competence- to make a factual record, to apply its expertise, and to correct its own errors so as to moot judicial controversies"); Weinberger v. Salfi, 422 U.S. 749, 765 (1975); National Conservative Pol. Action Comm. v. Federal Election Comm'n, 626 F.2d 953, 957 n.8 (D.C. Cir. 1980); Murillo v. Mathews, 588 F.2d 759, 761 ( 9 th Cir. 1978); Hayes v. Secretary of Defense, 515 F.2d 668, 670 (D.C. Cir. 1975). 
ficient to justify a rule preventing judicial intervention. Together, however, they form a whole greater than the sum of its parts. For all of the rationales display an underlying interest in preserving the administrative process as an effective and independent means of adjudication and regulation. This implies that administrative proceedings as such deserve not to be interrupted by the courts, absent some very pressing contrary interest. Indeed, the McKart Court went on to say that

[c]losely related to [these] . . . reasons is a notion peculiar to administrative law. The administrative agency is created as a separate entity and invested with certain powers and duties. The courts ordinarily should not interfere with an agency until it has completed its action, or else has clearly exceeded its jurisdiction. ... " [t]he exhaustion doctrine is, therefore, an expression of executive and administrative autonomy." 11

Furthermore, the Court found reasons for requiring exhaustion that, it said, "have nothing to do with the dangers of interruption of the administrative process." 12 One of these reasons, based upon "very practical notions of judicial efficiency," requires a litigant to vindicate her rights within the administrative process, if possible, to conserve judicial resources. ${ }^{13}$ In addition, said the Court, "notions of administrative autonomy require that the agency be given a chance to discover and correct its own errors." 14 Also, the Court shunned the "possib[ility] that frequent and deliberate flouting of administrative processes could weaken the effectiveness of an agency by encouraging people to ignore its procedures." 15 This last point is of particular importance because it

11 McKart, 395 U.S. at 194 (footnote omitted).

12 Id. 194-95. Why these reasons "have nothing to do with" the policy against intervention in administrative proceedings is far from clear. Rather, they appear to be reasons that actually support that policy, inasmuch as all are factors militating against interruption. Perhaps the Court meant to distinguish these reasons on the ground that they apply even when resort to administrative procedures is no longer possible. This would make sense in light of the particular facts of McKart. See id. 194.

13395 U.S. at 195 (emphasis added); Uniroyal, Inc. v. Marshall, 579 F.2d 1060, 1064 (7th Cir. 1978) (the exhaustion requirement avoids collateral, dilatory action and ensures efficient, uninterrupted progression of administrative proceedings and effective application of judicial review).

14395 U.S. at 195 (emphasis added). See L. JAFFe, Judictax Control of Administrative Action 425 (1965).

15395 U.S. at 195 (emphasis added). See McGee v. United States, 402 U.S. 479,484 (1971) (quoting McKart, 395 U.S. at 195). Cf. Sheehan v. Secretary of HEW, 593 F.2d 323, 327 (8th Cir. 1979) ("harsh result" justified by "necessity to maintain orderly review [that] requires compliance with orderly procedures"). 
emphasizes that rules governing the timing of judicial review of agency décisions should not be so vague or lax as to give litigants incentive to challenge agencies at every turn. While judicial efficiency may certainly be promoted by a rule encouraging parties to settle their differences in an administrative forum, the Court seems equally, if not primarily, concerned with promoting the integrity of the administrative process. Whether the exhaustion rule is justified by concern for administrative "integrity" or with conserving judicial and administrative resources, however, the result is the same: the courts should refrain in most cases from intervening in administrative proceedings. Not only does interruption disturb the decisionmaking authority of the administrative process by eroding its autonomy, but also the mere fact that proceedings are interrupted has a jarring effect upon the efficiency of both agencies and courts-regardless of the ultimate outcome. Evidently, it was in order to avoid these problems that the courts introduced the exhaustion doctrine.

\section{B. Exceptions}

As a discretionary principle, the exhaustion doctrine is not an absolute bar to judicial review of ongoing administrative proceedings, despite the strong policies favoring nonintervention. The courts have not applied exhaustion mechanically, ${ }^{16}$ often making decisions whether to require exhaustion "seemingly influenced by considerations other than those that strictly relate to exhaustion." 17 This flexible judicial approach has resulted in several common, and some less common, exceptions to the exhaustion requirement. ${ }^{18}$

16 NLRB v. Industrial Union of Marine Workers, 391 U.S. 418,426 n.8 (1968) ("exhaustion is a matter within the sound discretion of the courts"); McGee, 402 U.S. at 485 (application of the doctrine "should be assessed in light of a discrete analysis of the particular default in question, to see whether there is a governmental interest compelling enough' to justify the forfeiting of judicial review") (quoting McKart, 395 U.S. at 197); Montgomery v. Rumsfield, 572 F.2d 250, 253 (9th Cir. 1978) (judicially developed exhaustion requirements are inherently susceptible to judicial refinement and modification); Neely v. United States, 285 F.2d 438, 443 (Ct. Cl. 1961) ("unless made a prerequisite to suit by statute, binding regulation or contract, the extent to which a plaintiff is required to pursue his administrative remedy is a matter for the discretion of the court") (citations omitted). But see Hills v. Eisenhart, 256 F.2d 609, 611 (9th Cir.), cert. denied, 358 U.S. 832 (1958); Herriges v. United States, 314 F. Supp. 1352, 1354 (D. Mont. 1970) (failure to exhaust denies jurisdiction to the federal courts).

17 K. Davis, Admunstrative Law of the Seventies \$20.01 (1976).

18 McKart v. United States, 395 U.S. 185, 193 (1969). See Rhodes v. United States, 574 F.2d 1179, 1181 n.4 (5th Cir. 1978) ("undertaking to enumerate a complete list [of exceptions] presents a more difficult challenge because of a lack 
There is, however, a fundamental tension between certain of the policies supporting the exhaustion rule and the wide degree of judicial discretion represented by the many exceptions to the rule. Whereas the exhaustion requirement prevents the courts from violating the integrity of the administrative process, the exceptions to the doctrine threaten to erode that protection beyond repair. It is beyond dispute, however, that occasions arise during the course of administrative proceedings that cry out for judicial review. Such occasions no doubt account for the emergence of the exhaustion exceptions in the first place. The crucial question is how the balance between the competing interests is to be struck.

Whenever the courts intervene in ongoing administrative proceedings, the administrative process may be disrupted in two ways. The first of these is somewhat subtle, in that it relates to notions of authority and stature. When an intervening court decides adversely to an administrative agency, the decision will inevitably-if incrementally-undermine the agency's decisionmaking authority. The mere fact that the court may be correct and the agency wrong does not necessarily justify the court's interference in the administrative process. The agency's internal appeal mechanisms could still vindicate the party seeking review in the courts. Furthermore, subsequent levels of agency review may develop facts and reveal circumstances that change drastically the status of the case. The fact remains, however, that judicial intervention reduces the stature and legitimacy of the administrative process, particularly in the eyes of those who must interact with it. Not only is this lamentable as such, but it also further encourages litigants to by-pass or evade agency decisionmaking.

The administrative process is disturbed in a second way by judicial intervention. Regardless of whether or not the court ultimately reverses the agency decision, the bare fact that the proceedings are halted long enough for the parties to battle in court will invariably disrupt the agency's business. Even if the move to court is at bottom unjustified, court, agency and party time will have to be spent determining, at least, whether the claim falls within one of the exhaustion exceptions. More time may be spent appealing a decision believed adverse. The existence of broad and ambiguous exceptions to the exhaustion requirement can only encourage disgruntled litigants before administrative agencies to

of consistency among reported cases"); K. Davis, Administrative LAW of taE SEVENTIES $\$ 20.01$, at 446 (1976) ("The common judicial statement that one must exhaust administrative remedies before going to court is false almost as often as it is true."). 
seek judicial review before the conclusion of formal proceedings. Obviously, the broader and less definite the dimensions of the exception, the more opportunities exist for a litigant to argue that her case falls within it, as well as for the court to find that it can take the case. Each such case "weaken[s] the effectiveness of an agency by encouraging people to ignore its procedures," 19 thereby disserving the policies underlying exhaustion.

The following sections canvass the exceptions to exhaustion developed by the courts and describe how they may unacceptably interfere with the integrity of the administrative system.

\section{The Jurisdictional Exception}

One often-invoked exception ${ }^{20}$ to the exhaustion rule involves challenges to an agency's jurisdiction. This exception was first suggested by the Supreme Court in Skinner \& Eddy Corp. v. United States $^{21}$ and later confirmed in Leedom v. Kyne. ${ }^{22}$ Leedom per-

19 McKart, 395 U.S. at 195. The dearth of cases in which the courts actually reach the merits of a claim, rather than dismiss for failure to exhaust, do not undermine this argument. The point is made simply by reference to the innumerable cases in which parties to agency proceedings have sought review. The fact that many or most courts exercise their discretion to turn back such cases would indicate only that these intervention requests lack sufficient merit or basis to justify judicial intervention.

20 Professor Davis has speculated that "[p]erhaps half of all exhaustion problems on which courts write opinions involve attempts to challenge the jurisdiction of an agency in advance of completion of an administrative proceeding." K. DAvIs, Administrative LaAw Text $\$ 20.02$ (3d ed. 1972).

21249 U.S. 557 (1919).

22358 U.S. 184 (1958). In Leedom, the NLRB certified a bargaining unit composed of both professional and nonprofessional employees. This certification was not preceded by an election to ascertain whether the professional employees favored including the nonprofessionals in their unit, although such an election was expressly required by $\$ 9$ (b)(1) of the National Labor Relations Act, 29 U.S.C. $\S 159(\mathrm{~b})(1)(1976)$.

The Board ordered an election to determine which of two competing unions would represent the unit, and one of those unions moved the Board to stay the election and exclude the nonprofessionals. The Board refused and held the election. The union then filed suit in district court, seeking to set aside the Board's action. The Board moved to dismiss for want of jurisdiction, but the district court, finding that the Board had improperly commingled employees, granted the union's motion for summary judgment. The court of appeals, rejecting the Board's jurisdictional argument, affirmed. 249 F.2d 490 (D.C. Cir. 1957).

Before the Supreme Court, the Board contended that a certification order was unreviewable except as it might bear on an unfair labor practice enforcement proceeding. This position seemed logical in light of the Court's holding in American Federation of Labor v. NLRB, 308 U.S. 401 (1940), that a certification order was not "final" and so did not vest the Court with jurisdiction to review the case. It also comported with language in $\$ 9$ of the National Labor Relations Act, 29 U.S.C. $\$ 159$ (1976). The Court disagreed with these arguments and held that the district court had jurisdiction because the suit was

not one to "review," in the sense of that term as used in the Act, a decision of the Board made within its jurisdiction. Rather it is one to 
mits a court to intervene in administrative proceedings if the agency has exceeded its jurisdictional limits. The Supreme Court ${ }^{23}$ and most lower courts ${ }^{24}$ have construed the Leedom exception narrowly. This narrow exception, "rarely successfully invoked," 25 has been correctly used by federal courts "to check-not to supplant -administrative action." 26

An alternative approach to challenges to an agency's jurisdiction, however, threatens to expand the narrow Leedom interpretation and consequently permit increased judicial interruption of ongoing agency proceedings. This approach, initially advocated by Professor Davis, ${ }^{27}$ has since been adopted by the Ninth Circuit. ${ }^{28}$ Under this approach, the question whether a court should intervene to determine whether an agency has jurisdiction over a given case turns on an assessment of three factors: the extent to which the parties will be injured if forced to pursue their administrative remedies; the degree of clarity or doubt about agency jurisdiction; and the need for administrative expertise in resolving the jurisdictional issue. ${ }^{29}$ Professor Davis has acknowledged that an evaluation

strike down an order of the Board made in excess of its delegated powers and contrary to a specific prohibition in the Act.

358 U.S. at 188 (emphasis added).

23 Boire v. Greyhound Corp., 376 U.S. 473, 481 (1964).

24 American Gen. Ins. Co. v. FTC, 496 F.2d 197, 200 (5th Cir. 1974) (jurisdictional violation must be "gross or egregious"); United States v. Feaster, 410 F.2d 1354, 1368 (5th Cir.), cert. denied, 396 U.S. 962 (1969) (jurisdictional violation must be "egregious"); Allegheny Airlines, Inc. v. Fowler, 261 F. Supp. 508, 520 (S.D.N.Y. 1966) ("palpably unconstitutional"). But see text accompanying notes $67-153$ infra.

25 United States v. Feaster, 410 F.2d 1354, 1368 (5th Cir.), cert. denied, 396 U.S. 962 (1969).

26 Finat Report of the Attorney General's Committee on Admansstrative PROCEDURE 77 (1941) (emphasis in original).

273 K. Davis, Admonstratne Law Treatise $\$ 20.03$ (1958).

28 Casey v. FTC, 578 F.2d 793, 796 (9th Cir. 1978); California ex rel. Christensen v. FTC, 549 F.2d 1321, 1323 (9th Cir.), cert. denied, 434 U.S. 876 (1977); Lone Star Cement Corp. v. FTC, 339 F.2d 505, 510 (9th Cir. 1964). The continued vitality of the Davis approach to jurisdictional claims in the Ninth Circuit was drawn into question by Marshall v. Burlington N., Inc., 595 F.2d 511, 513 (9th Cir. 1979). See note 29 infra.

No other circuit has adopted the Davis approach. It has not, however, gone unnoticed elsewhere. The Fifth Circuit applied the Davis test in Frito-Lay, Inc. v. FTC, 380 F.2d 8, 10 (5th Cir. 1967). Accord, Central Hudson Gas \& Elec. Corp. v. EPA, 587 F.2d 549, 563 (2d Cir. 1978) (Feinberg, J., concurring); Bailey v. United States, 451 F.2d 963, 968 (5th Cir. 1971) (Clark, J., dissenting).

$29 \mathrm{~K}$. Davis, Adminstratrve Law Texx $\$ 20.03$ (3d ed. 1972). It is open to question whether a recent Ninth Circuit decision has altered the status of the Davis approach in that circuit. Citing Casey, California ex rel. Christensen, Lone Star Cement, and the Davis treatise, the court restated its approach to agency jurisdictional challenges as follows:

Judicial intervention prior to an agency's initial determination of its jurisdiction is appropriate only where: (1) there is clear evidence that 
of these factors involves a large element of judgment, and that a "workable standard probably should not go beyond a statement that each of these factors should be weighed in determining whether or not a court should decide an issue of administrative jurisdiction without requiring exhaustion of administrative remedies." 30

The Davis approach represents a substantial departure from the narrow Leedom exception. The focus of the Leedom line of cases is on whether an agency clearly lacks jurisdiction. If the pleadings do not make clear that the agency has exceeded its statutory mandate, Leedom requires exhaustion. In contrast, the Davis approach requires, at least, limited judicial intervention to consider problematic claims of jurisdiction. If an agency's jurisdiction is brought into question, a court must consider the propriety of intervention in light of the three articulated factors. ${ }^{31}$ Because a thorough consideration of these three factors undoubtedly involves some consideration of the merits of a case, such an approach encourages, rather than discourages, judicial intervention in ongoing agency proceedings.

\section{The Constitutional Exception}

Another exception to the exhaustion requirement arises when agency action allegedly violates a litigant's constitutional rights. The Second Circuit proposed this exception in Fay v. Douds: ${ }^{32}$ "If this assertion of constitutional rights is not transparently friv-

exhaustion of administrative remedies will result in irreparable injury;

(2) the agency's jurisdiction is plainly lacking; and (3) the agency's spe-

cial expertise will be of no help on the question of its jurisdiction.

Marshall v. Burlington N., Inc., 595 F.2d 511, 513 (9th Cir. 1979) (emphasis added). The Marshall analysis, if followed literally, would eviscerate Davis's discretionary approach. Moreover, it would actually impose a more formidable barrier to judicial consideration of jurisdictional claims than the Leedom line of cases presently imposes. Under Leedom, judicial consideration is warranted when agency jurisdiction is plainly lacking. See notes 20-26 supra \& accompanying text. Under Marshall, however, there is an additional requirement that there be clear evidence that exhaustion will cause irreparable injury.

$30 \mathrm{~K}$. Davis, Admmistrative Law Text $\$ 20.03$ (3d ed. 1972).

31 See text accompanying note 29 supra.

32172 F.2d 720 (2d Cir. 1949).

In Fay, the plaintiff labor union brought an action in district court to enjoin an NLRB election that, with the employer's consent, involved a rival union. The plaintiff also sought to compel the Board to hold an evidentiary hearing on its complaint. The district judge dismissed the complaint. 79 F. Supp. 582 (S.D.N.Y. 1948). On appeal, the plaintiff union contended that it possessed a "property right" in maintaining its position as the involved employees exclusive bargaining agent, and that the Board's refusal to hold a hearing denied that right without due process 
olous, it gave the District Court jurisdiction; and, having once acquired jurisdiction, the court might, and should, dispose of all other questions which arose, even though they would not have been independently justiciable." ${ }^{33}$ Although the courts of appeals seem to be retreating from $\mathrm{Fay}_{3}{ }^{34}$ the exhaustion exception for constitu-

of law. It was this contention that, according to the Second Circuit, gave the district court jurisdiction to hear the case. 172 F.2d at 723 .

Note that Fay did not involve an exhaustion question; the Board's denial of a hearing exhausted the union's only available remedy. It is, therefore, remarkable that Fay stands for the proposition that agency action potentially infringing constitutional rights excuses plaintiffs from the exhaustion requirement.

33172 F.2d at 723 (footnote omitted).

34 Second Circuit: see Association of Nat'l Advertisers v. FTC, 565 F.2d 237, 239 (2d Cir. 1977) (mentioning constitutional rights solely in the context of appealing nonfinal orders, but concluding that there were "no administrative remedies available to appellant .... Appellant had, therefore, exhausted its administrative remedies when it filed suit." Thus, the discussion of Fay appears to be dicta.); Herald Co. v. Vincent, 392 F.2d 354, 359 (2d Cir. 1968) (refusing to decide whether Fay is still authoritative); Utica Mut. Ins. Co. v. Vincent, 375 F.2d 129, 134 (2d Cir. 1967) (same). See also Moshlak v. American Broadcasting Co., 423 F. Supp. 774, 778 (S.D.N.Y. 1976) (expressing doubt about Fay's viability in the Second Circuit).

Third Circuit: see NLRB v. Interstate Dress Carriers, Inc., 610 F.2d 99, 107 (3d Cir. 1979) (Fay "has never been approved by the Supreme Court, and has shown little growth potential, either in the Second Circuit . . . or elsewhere"); United States Metal Co. Employees' Ass'n v. NLRB, 478 F. Supp. 861, 864 (W.D. Pa. 1979) (Third Circuit has not accepted Fay); National Maritime Union v. NLRB, 375 F. Supp. 421, 435 (E.D. Pa.), aff'd mem., 506 F.2d 1052 (3d Cir. 1974), cert. denied, 421 U.S. 963 (1975) (same).

Fourth Circuit: see J.P. Stevens Employees Educ. Comm. v. NLRB, 582 F.2d 326, 329 (4th Cir. 1978) (finding Fay unpersuasive).

Fifth Circuit: see Coca-Cola Co. v. FTC, 475 F.2d 299, 303 (5th Cir. 1973) (Fay is "probably correct" but it has only limited application); Boire v. Miami Herald Publishing Co., 343 F.2d 17, 21 n.7 (5th Cir. 1965) (questioning whether Fay has been accepted by the Fifth Circuit).

Sixth Circuit: see Blue Cross \& Blue Shield v. NLRB, 609 F.2d 240, 244-45 (6th Cir. 1979) (rejecting Fay).

Seventh Circuit: see Grutka v. Barbour, 549 F.2d 5, 9 n.7 (7th Cir.), cert. denied, 431 U.S. 908 (1977) (If still viable, Fay applies only to "a vested property right with respect to a collective bargaining agreement where he has no way of ultimately obtaining judicial review."); Maremont Corp. v. FTC, 431 F.2d 124, 128 (7th Cir. 1970) (constitutional claim should be raised after completion of agency proceedings); American Auto. Ass'n v. Squillacote, 310 F. Supp. 596, 598-99 (E.D. Wis. 1970) (distinguishing Fay, but recognizing that its wisdom has been questioned).

Eighth Circuit: see Meat Cutters Local 576 v. Allen, 423 F.2d 267, 269 (8th Cir. 1970) (refusing to decide the viability of Fay because plaintiff's constitutional claim was "wholly frivolous"); Cihacek v. NLRB, 464 F. Supp. 940, 945 (D. Neb. 1979) (questioning Fay on the authority of Meat Cutters).

Ninth Circuit: see Squillacote v. Teamsters Local 344, 561 F.2d 31 (9th Cir. 1977) ("whatever is left of the Fay doctrine applies only to situations in which the party seeking to invoke the equity jurisdiction of the district court asserts ' $a$ vested property right with respect to a collective bargaining agreement where he has no way of ultimately obtaining judicial review" ) (quoting Grutka v. Barbour, 549 F.2d 5, 9 n.7 (7th Cir. 1977)), cert. denied, 43I U.S. 908 (1977). D.C. Circuit: see Wallace v. Lynn, 507 F.2d 1186, 1190-91, 1191 n.28 (D.C.

Cir. 1974) (exhaustion doctrine applies to constitutional claim). 
tional claims is frequently mentioned in lower court decisions ${ }^{35}$ and remains alive in the Supreme Court. ${ }^{36}$

Courts applying Fay usually try to avoid disrupting the administrative process by requiring as a predicate to judicial intervention something beyond a mere allegation that constitutional deprivations have occurred. ${ }^{37}$ Some courts interpret the "not transparently frivolous" 38 language of Fay to require a "substantial showing" that a constitutional right has been abridged. ${ }^{39}$ Others insist that the violation be "clear" or "very clear." 40

The problem with these seemingly narrow approaches is the discretion a court has in assessing what constitutes a "clear" constitutional violation. This discretion enables a court to decide that almost any alleged constitutional violation is serious enough

35 See, e.g., First Jersey Sec., Inc. v. Bergen, 605 F.2d 690, 697 (3d Cir. 1979), cert. denied, 100 S. Ct. 1020 (1980); Rosenthal \& Co. v. Bagley, 581 F.2d 1258, 1261 (7th Cir. 1978); Association of Nat'l Advertisers v. FTC, 565 F.2d 237, 239 (2d Cir. 1977); Seven-Up Co. v. FTC, 478 F.2d 755, 757 (8th Cir.), cert. denied, 414 U.S. 1013 (1973); Coca-Cola Co. v. FTC, 475 F.2d 299, 303 (5th Cir.), cert. denied, 414 U.S. 877 (1973); Fitzgerald v. Hampton, 467 F.2d 755, 769 (D.C. Cir. 1972); Balanyi v. Local 1031, IBEW, 374 F.2d 723, 726 (7th Cir. 1967).

36 In Califano v. Sanders, 430 U.S. 99 (1977), the Supreme Court stated: Constitutional questions obviously are unsuited to resolution in administrative hearing proceedings and, therefore, access to the courts is essential to the decision of such questions .... [W] [Wen constitutional questions are in issue, the availability of judicial review is presumed, and we will not read a statutory scheme to take the "extraordinary" step of foreclosing jurisdiction unless Congress' intent to do so is manifested by "clear and convincing" evidence.

Id. 109. See Mathews v. Diaz, 426 U.S. 67 (1976) (constitutional challenge heard when beyond the agency's competence); Mathews v. Eldridge, 424 U.S. 319, 332 (1976) (considering a constitutional claim because agency resolution on nonconstitutional grounds "would not answer [the claimant's] constitutional challenge"). But see Weinberger v. Salfi, 422 U.S. 749,762 (1975) (refusal to consider asserted constitutional violation because the constitutional claim had to be "brought under jurisdictional grants contained in the [agency's enabling statute] and thus in conformity with the same standards which are applicable to nonconstitutional claims arising under the [statute]").

37 But cf. Downen v. Warner, 481 F.2d 642, 643 (9th Cir. 1973) ("Resolving a claim founded solely on a constitutional right is singularly suited to a judicial forum and clearly inappropriate to an administrative board.").

38 Fay, 172 F.2d at 723.

39 See, e.g., Association of Nat'l Advertisers v. FTC, 565 F.2d 237, 239 (2d Cir. 1977); American Gen. Ins. Co. v. FTC, 496 F.2d 197, 199-200 (5th Cir. 1974); United States v. Feaster, 410 F.2d 1354, 1366 (5th Cir.) (quoting Boire, 343 F.2d at 21), cert. denied, 396 U.S. 962 (1969); Balanyi v. Local 1031, IBEW, 374 F.2d 723, 726 (7th Cir. 1967) (citing Boire, 343 F.2d at 21); Mount Sinai Hosp. v. Weinberger, 376 F. Supp. 1099,1120 (S.D. Fla. 1974), rev'd on other grounds, 517 F.2d 329 (5th Cir. 1975), cert. denied, 425 U.S. 935 (1976).

40 See, e.g., First Jersey Sec., Inc. v. Bergen, 605 F.2d 690, 696-97 (3d Cir. 1979), cert. denied, 100 S. Ct. 1020 (1980); Seven-Up Co. v. FTC, 478 F.2d 755, 757 (8th Cir.), cert. denied, 414 U.S. 1013 (1973); Sterling Drug, Inc. v. FTC, 450 F.2d 698, 710 (D.C. Cir. 1971). 
to require judicial resolution prior to the completion of agency proceedings. ${ }^{41}$ Perhaps more importantly, the mere presence of the constitutional-issue exception may encourage parties to seek judicial review, although their claims may lack merit. The administrative process is no less interrupted by "fishing expeditions" as by meritorious claims. Furthermore, the litigant who believes a constitutional violation has taken place will have, in either case, ultimate recourse to the courts. Consequently, litigants should not be able to seek and obtain judicial intervention merely by claiming a constitutional violation, except maybe in extraordinary circumstances.

\section{Inadequate Remedies}

A third exception, related to the preceding one, applies when administrative remedies are inadequate or when litigants will suffer irreparable injury if required to exhaust. Justice Rutledge's majority opinion in Aircraft \& Diesel Corp. $v$. Hirsch ${ }^{42}$ was one of the original formulations of this exception:

$[\mathrm{T}]$ he presence of constitutional questions, coupled with a sufficient showing of inadequacy of prescribed administrative relief and of threatened or impending irreparable injury flowing from delay incident to following the prescribed procedure, has been held sufficient to dispense with exhausting the administrative process before instituting judicial intervention. . . . [T] his rule is not one of mere convenience or ready application . . . a strong showing is required, both of inadequacy of the prescribed procedure and of impending harm, to permit short-circuiting the administrative process. ${ }^{43}$

41 One court, addressing the "clearly illegal" standard, aptly expressed this concern:

It may be argued that if administrative action is "clearly illegal" and if in any event it will be overturned in the process of administrative review, we should at the start save the parties the trouble and expense of pursuing their administrative remedies. Again the simplicity of the statement is deceiving. ...

In the realm of legal theory it may be that the phrase "clearly illegal" has a final and definite meaning but like so much other legal nomenclature when the time comes for application many difficulties are seen. What appears clearly illegal to one judge may be on the fringe of legality to another; to another, unsavory administrative action, but nevertheless the will of Congress.

Hardy v. Rossell, 135 F. Supp. 260, 265 (S.D.N.Y. 1955) (emphasis added). 42331 U.S. 752 (1947).

43 Id. 773-74. 
Rutledge's narrow formulation of this exception requires both a "strong showing" of inadequacy and irreparable injury, and claims of a constitutional dimension, in order to avoid exhaustion. Many courts have reformulated this exception, however, so that in most cases either impending irreparable injury or inadequacy will excuse the exhaustion requirement for any claim. ${ }^{44}$ This reformulation obviously provides more opportunities for judicial intervention in ongoing agency proceedings than does a strict construction of Aircraft of Diesel Corp. because it significantly reduces the burden upon the claimant.

\section{International Questions}

The Supreme Court announced the narrowest exception to the exhaustion requirement in $M c C$ ulloch $v$. Sociedad Nacional de Marineros. ${ }^{45}$ In $M c C u l l o c h$, the Court excused the petitioner's failure to exhaust on the theory that "the presence of public questions particularly high in the scale of our national interest because of their international complexion is a uniquely compelling justification for prompt judicial resolution of the controversy over the Board's power." 46 The Court noted that this exception was to be extremely narrowly construed, ${ }^{47}$ and it has rarely been used to excuse the failure to exhaust. ${ }^{48}$

44 E.g., Greene v. United States, 376 U.S. 149, 163 (1964) (no adequate remedy); Von Hoffman v. Alexander, 615 F.2d 633, 640-41 (5th Cir. 1980) (futile or inadequate remedy); Rosenthal \& Co. v. Commodity Futures Trading Comm'n, 614 F.2d 1121, 1128 (7th Cir. 1980) (irreparable injury); West v. Bergland, 611 F.2d 710, 718-19 (8th Cir. 1979) (irreparable injury or inadequate remedy), cert. denied, 49 U.S.L.W. 3215 (U.S. Oct. 7, 1980) (No. 791592); Babcock \& Wilcox Co. v. Marshall, 610 F.2d 1128, 1138 (3d Cir. 1979) (exhaustion futile); Marine Wonderland \& Animal Park v. Kreps, 610 F.2d 947, 949 (D.C. Cir. 1979) (irreparable injury); Touche Ross \& Co. v. SEC, 609 F.2d 570, 577 (2d Cir. 1979) (exhaustion futile); Humana v. Califano, 590 F.2d 1070, 1081 (D.C. Cir. 1978) (inefficacious remedy); Murillo v. Mathews, 588 F.2d 759, 763 (9th Cir. 1978) (fruitless); Rhodes v. United States, 574 F.2d 1179, 1181 (5th Cir. 1978) (no real opportunity for adequate relief); Sanders v. McCrady, 537 F.2d 1199 (4th Cir. 1976) (inadequate administrative remedy).

45372 U.S. 10 (1963). In McCulloch, the NLRB ordered a representation election among foreign seamen on foreign ships owned by American corporate subsidiaries. The Court permitted immediate judicial intervention, noting that the Board's action had aroused vigorous protests from foreign governments and had created international problems for the United States.

46 Id. 17.

47 Specifically, the Court stated that $M c C$ ulloch was "not to be taken as an enlargement of the exception in [Leedom v.] Kyne." Id. See notes 20-25 supra \& accompanying text.

48 But see NLRB v. Industrial Union of Marine \& Shipbuilding Workers, 391 U.S. 418,426 n.8 (1968) (union member not required to exhaust internal remedies when complaint raises a matter in "the public domain" and beyond union's 


\section{Inherently Legal Questions}

Another exhaustion exception of some import is invoked when the issue with respect to which judicial review is sought is "purely" or "inherently" legal.49 Although one court recently stated that the existence of a legal question "independently makes the exhaustion doctrine inapplicable," 50 this exception "is in practice heavily interwoven with other exceptions." 51 Because administrative agencies frequently encounter "legal" issues in their proceedings, allowing the mere existence of a legal issue to be an independent basis for judicial intervention could effectively deny agencies the opportunity to interpret the statutes they are authorized to apply. In addition, difficulty in determining which issues are "purely" or "inherently" legal may encourage litigants to seek review of otherwise unreviewable cases, by fostering the hope that the courts can be persuaded to excuse exhaustion.

\section{Waiver}

Even when a case does not fit into one of the aforementioned exhaustion exceptions, courts have some discretion to waive the exhaustion requirement if the reasons for doing so are compelling. ${ }^{52}$ The recent Supreme Court decisions of Weinberger $v$. Salf ${ }^{83}$ and Mathews $v$. Eldridge ${ }^{54}$ rather than restricting this discretion, have made federal courts, administrative agencies, and

internal affairs); Chambers v. Local 639, Int'l Bhd. of Teamsters, 578 F.2d 375, 386 (D.C. Cir. 1978) (plurality opinion) (exhaustion not required when complaint raises a matter "in the public domain").

49 Association of Nat'l Advertisers, Inc. v. FTC, 1980-1 Trade CAs. If 63098 (D.C. Cir. 1979); Borden, Inc. v. FTC, 495 F.2d 785, 787 (7th Cir. 1974); Sterling Drug, Inc. v. FTC, 450 F.2d 698, 710-11 (D.C. Cir. 1971); Jewel Cos. v. FTC, 432 F.2d 1155, 1159 (7th Cir. 1970). But see McKart v. United States, 395 U.S. 185, 205 (1969) (White, J., concurring); St. Regis Paper Co. v. Marshall, 591 F.2d 612, 614 (10th Cir.), cert. denied, 444 U.S. 828 (1979); American Gen. Ins. Co. v. FTC, 496 F.2d 197, 200 (5th Cir. 1974).

50 Dow Chem. v. Consumer Prod. Safety Comm'n, 459 F. Supp. 378, 388 (W.D. La. 1978) (emphasis added).

61 Zacharias, supra note 1 , at 26.

62 See note 16 supra.

53422 U.S. 749 (1975).

54424 U.S. 319 (1976).

The statute involved in Salfi and Eldridge, 28 U.S.C. $\$ 405(\mathrm{~g})$ (1976), requires a "final decision" prior to judicial review. The Court, however, interpreted a final decision as "one in which the Secretary may specify such requirements for exhaustion as he deems serve his own interests in effective and efficient administration." 422 U.S. at 766 (emphasis added). Because the Court is discussing exhaustion requirements, its discussion is clearly relevant to the exhaustion doctrine as such. 
parties to administrative proceedings increasingly uncertain about when exhaustion of administrative remedies is required, when discretionary, and when unnecessary altogether.

In Weinberger $v$. Salfi, the Court held that the federal courts are not entitled to assume jurisdiction absent a waiver by the administrative agency of the exhaustion requirement. A court could not "substitute its [own] conclusion as to futility [of the administrative remedy] for the contrary conclusion of the Secretary." ${ }_{55}$ The Court, however, presumed agency waiver of exhaustion from the fact that the agency did not "raise any challenge to the sufficiency of the allegations of exhaustion in [the] . . complaint." 56

Justice Brennan's dissent in Salfi pointed out several problems with the Court's new formulation of the exhaustion doctrine. The agency waiver requirement, according to Brennan, does not protect the claimant's interest in avoiding futile remedies and presents opportunities for "lawless application" of the exhaustion doctrine because an agency could choose at its whim whether to require exhaustion. $^{57}$ Because the agency had moved in district court to dismiss the entire action for lack of subject matter jurisdiction, explicitly stating that no exhaustion had occurred, Justice Brennan also criticized the Court's finding that the agency had waived exhaustion. ${ }^{58}$

Justice Brennan's concern with "lawless application" of the cxhaustion doctrine was laid to rest in Mathews v. Eldridge. In that case, an agency refused to waive the exhaustion requirement and moved to dismiss the case for lack of jurisdiction, under Salfi.59 The Court rejected the agency's argument, interpreting Salf $i$ as having established two elements of exhaustion. The first or "nonwaivable" element-presenting a claim to the agency for administrative review-served as an absolute bar to judicial review. The second or "waivable" element-exhausting the actual remedies prescribed by the agency-could be waived by the agency. ${ }^{60}$

The difficulty with Eldridge is that the Court assumed jurisdiction even though the "waivable element" of exhaustion was not waived. Justice Powell's majority opinion explained this anomaly on the ground that "cases may arise where a claimant's interest in having a particular issue resolved promptly is so great that defer-

55422 U.S. at 766.

56 Id. 767.

57 Id. 800-0I (Brennan, J, dissenting).

58 Id. 801-02.

59424 U.S. at 328.

60 Id. 328-32. 
ence to the agency's judgment [that exhaustion is required] is inappropriate."

A serious problem with Salfi and Eldridge is that the application of the exhaustion doctrine, now depending on both an agency and a court decision, has become even more unpredictable. The agency has the right either to waive or not waive exhaustion, but a federal court has the power, in its discretion, to effect a "waiver" without the agency's consent and against its will. Stated in practical terms, the undesirable consequence of these two decisions is that "the law that emerges is so complex that it cannot possibly be administered by the lower courts without undue litigation." ${ }^{2} 2$

\section{The Emerging Reliance on Finality}

During the last decade, a complementary approach to the problem of judicial intervention in ongoing administrative proceedings has emerged. This approach focuses on the "final agency action" requirement in the long-ignored ${ }^{63}$ section $10(c)$ of the Administrative Procedure Act (APA). ${ }^{64}$ This section provides:

Agency action made reviewable by statute and final agency action for which there is no other adequate remedy in a court are subject to judicial review. A preliminary, procedural, or intermediate agency action or ruling not directly reviewable is subject to review on review of the final agency action. Except as otherwise expressly required by statute, agency action otherwise final is final for the purposes of this section whether or not there has been presented or determined an application for a declaratory order, for any form of reconsiderations, or, unless the agency otherwise requires by rule and provides that the action meanwhile is inoperative, for an appeal to superior agency authority ${ }^{65}$

Two appellate judges have developed useful frameworks for the application of section 10(c)'s requirement of "final agency ac-

61 Id. 330.

$62 \mathrm{~K}$. Davis, Administrative Law of the Seventies $\$ 20.00-3$ (Supp. 1980).

$63 \mathrm{~K}$. Davas, Admmistrative Law of the Seventzes $\$ 20.08$ (1976). See also id. $\$ 20.04$ (discussing cases which could have been analyzed in terms of $\S 10$ (c) of the Administrative Procedure Act, 5 U.S.C. $\$ 704$ (1976), but were not).

645 U.S.C. $\$ 704$ (1976). The general judicial review provisions of this section may be supplemented or abrogated by the enabling legislation of an administrative agency.

65 Id. (emphasis added). 
tion." They are Judge Friendly of the Second Circuit and Judge Leventhal of the District of Columbia Circuit. ${ }^{66}$

\section{A. Judge Friendly's Approach}

The development of finality analysis in the Second Circuit began with Pepsico, Inc. v. Federal Trade Commission. ${ }^{67}$ In that case, the FTC had filed a complaint against Pepsico, seeking to prohibit it from taking certain actions with respect to its bottlers. ${ }^{68}$ Pepsico pleaded as a defense that its 513 bottlers were indispensable parties to the proceedings and moved to dismiss due to the FTC's failure to join them. The hearing examiner denied the motion, ${ }^{69}$ and Pepsico filed an interlocutory appeal. When the Commission affirmed the decision of the examiner, ${ }^{70}$ Pepsico brought an action in district court, seeking to enjoin the FTC from proceeding against it unless the bottlers were joined. The district court dismissed for lack of jurisdiction. ${ }^{71}$ The court of appeals affirmed. ${ }^{72}$

Judge Friendly, in the opinion for the court of appeals, seemed to accept that the exhaustion rule was inadequate to bar judicial review under the circumstances of the case because Pepsico had exhausted its administrative remedies as to the joinder issue for which review was sought. ${ }^{73}$ But to allow review under these circumstances would have entailed an undesirable interruption of an ongoing agency proceeding.

Owing to the exhaustion doctrine's shortcomings, Judge Friendly rejected it as the basis of analysis and focused instead upon "the crucial issue [of] ... the proper interpretation of $\S 10(\mathrm{c})$." 74

${ }^{86}$ See notes 67-107 infra \& accompanying text.

Various other courts have also applied the "final agency action" requirements of $\S 10(\mathrm{c})$. See, e.g., Ideal Basic Indus., Inc. v. Morton, 542 F.2d 1364, 1370 (9th Cir. 1976); Gallo v. Mathews, 538 F.2d 1148, 1151 (5th Cir. 1976); Klein v. Comm'r of Patents, 474 F.2d 821, 824 (4th Cir. 1973); United States v. Consolidated Mines \& Smelting Co., 455 F.2d 432, 452 (9th Cir. 1971); Nor-Am Agricultural Products, Inc. v. Hardin, 435 F.2d 1151, 1159 (7th Cir. 1970); Mount Sinai Hosp., Inc. v. Weinberger, 376 F. Supp. 1099, 1123-26 (S.D. Fla.), rev'd on other grounds, 517 F.2d 329 (5th Cir. 1975).

67472 F.2d 179 (2d Cir. 1972), cert. denied, 414 U.S. 876 (1973).

68 Id. 182.

69 Id. 183.

70 The Commission chose not to treat the matter as a motion for leave to file an interlocutory appeal. Instead, the Commission treated the question as though it had been certified to it with the hearing examiner's recommendation. Id.

71 Id.

72 Id. 191.

73 Id. 186 n.7.

74 Id. 186. See text accompanying note 124 infra. 
The court dismissed Pepsico's complaint on the merits, ${ }^{75}$ but also found that there had been no "final agency action." 76

Judge Friendly postulated, accepting only "for the sake of argument," 77 that forms of "final agency action," and hence occasion for judicial intervention in agency proceedings, might exist when an agency "refuses to dismiss a proceeding that is plainly beyond its jurisdiction as a matter of law or is being conducted in a manner that cannot result in a valid order." 78 The reason for including these two situations within a definition of final agency action, in Judge Friendly's view, might be derived from Leedom $v$. Kyne $^{79}$ and McCulloch v. Sociedad Nacional de Marineros. ${ }^{80}$ Judge Friendly suggested in Pepsico that this standard represents a "possibly over-generous" reading of those cases ${ }^{81}$ and noted, in a subsequent case, that these two situations are "the most that can be extrapolated from Leedom v. Kyne." 82

The finality approach resurfaced in Ecology Action v. Atomic Energy Commission. ${ }^{83}$ The Atomic Energy Commission issued an order excluding certain issues from consideration in proceedings on an application for the construction of a nuclear power plant. ${ }^{84}$ Ecology Action sought review of this order as "final," claiming that the Commission's exclusionary ruling would render the administrative proceeding incapable of resulting in a valid order, thus bringing the case within Pepsico's arguably broad grounds for review. ${ }^{85}$ The Second Circuit dismissed Ecology Action's petition for review for lack of jurisdiction. ${ }^{86}$

Judge Friendly, writing for the court, recognized that an administrative order need not be the last possible one to constitute a "final" order. ${ }^{87}$ He nonetheless rejected Ecology Action's contention that this was a case of final agency action:

75472 F.2d at 190-91.

76 Id. 187.

77 Id.

7s Id. (footnote omitted).

79358 U.S. 184 (1958). See notes 20-31 supra \& accompanying text.

80372 U.S. 10 (1963). See notes $45-48$ supra \& acompanying text.

81472 F.2d at 187.

82 Sterling Drug, Inc. v. Weinberger, 509 F.2d 1236, 1239 (2d Cir. 1975). In Sterling Drug, Judge Friendly seems to adopt the view that both exceptions to the exhaustion requirement that he recognized in Pepsico could be extrapolated from Leedom v. Kyne alone. Id.

83492 F.2d 998 (2d Cir. 1974).

S4 Id. 999.

85 Id. 1001.

86 Id. 1002.

87 Id. 1000. 
If there is to be an exception [to the rule that such claims are reviewable only upon ultimate judicial review of an agency's final order], it should be limited to cases where the exclusionary ruling is so flagrantly wrong and demonstrably critical as to make it apparent that the agency is not merely courting the possibility of reversal but is running into the certainty of it if the ultimate decision should be against the proponent of the evidence. In that exceedingly limited category, the game of bestowing the rubric of finality on an order which, from an analytical standpoint, is surely interlocutory, may be worth the candle. ${ }^{88}$

Judge Friendly acknowledged that the application of such a rule would require some consideration of the merits of the claim. He contended, however, that an approach affording "a little play in the joints for judgment" would be preferable to holding that such exclusionary orders could never constitute "final agency action." 89

In sum, Judge Friendly's approach would posit administrative finality, under either section $10(\mathrm{c})$ of the APA or the judicial review provisions of an agency's enabling statute, as a prerequisite to judicial intervention in agency proceedings. Judge Friendly's approach, although initiated by an inquiry into jurisdiction, ultimately renders discretionary the decision whether to review agency action during a continuing proceeding. Judges less reluctant than Judge Friendly to intervene in ongoing administrative proceedings are afforded sufficient discretion, by playing the semantic "game of bestowing the rubric of finality on an order," ${ }^{30}$ to step in at virtually any point to second-guess the challenged agency. Judge Friendly's focus on "final agency action," however, has been beneficial; his opinions have exposed the inadequacies of using the exhaustion doctrine alone to assess the appropriateness of judicial intervention in an ongoing administrative proceeding.

\section{B. Judge Leventhal's Approach}

In Association of National Advertisers (ANA) v. Federal Trade Commission, ${ }^{91}$ the ANA sought declaratory relief in district court after FTG Chairman Pertschuk refused-with the Commission's

88 Id. 1001.

89 Id.

$90 \mathrm{Id}$.

01 1980-1 Trade Cas. $\int 63098$, at 77,461 (D.C. Cir. 1979), cert. denied, 100 S. Ct. 3011 (1980). 
backing-to recuse himself from rulemaking proceedings affecting the ANA. Plaintiffs claimed that Pertschuk had prejudged the issues, and for ammunition, they pointed to certain public statements that Pertschuk had made concerning the subject of the rulemaking. ${ }^{92}$ The district court granted the requested relief. ${ }^{93}$ On appeal, the District of Columbia Circuit reversed the district court's order. ${ }^{04}$ But the circuit court did not think its immediate review of the challenge to Chairman Pertschuk's participation was barred by the exhaustion doctrine. ${ }^{95}$

Judge Leventhal, concurring in the judgment, focused upon the "jurisdictional difficulty [that] arises out of the requirement of finality" ${ }^{96}$ under section $10(\mathrm{c})$. He suggested that this section requires "more than exhaustion of administrative remedies, [in that] it also requires a final agency action." ${ }^{97}$ In his view this requirement constituted a "general denial of jurisdiction" 98 in courts to interfere prior to final agency action.

Judge Leventhal offered two narrow exceptions to this jurisdictional barrier. The first, in complete conformity with Leedom $v$. Kyne, would allow judicial intervention when an agency had "clearly violated an express statutory prohibition." 89 The second exception to the finality requirement would obtain when the agency commits a "violation of basic rights established by a structural flaw, and not requiring in any way a consideration of interrelated aspects of the merits." 100 Except for these exceptions, "[a] court must disclaim jurisdiction notwithstanding the claim that action already taken realistically means that the ongoing proceeding will be waste motion and will have to be done over again." 101

Judge Leventhal also suggested that a court faced with a party seeking relief for "a claim of prejudice or bias alleged to infect an

92 Id. 77,477 n.56.

93 Id. 77,463 .

$94 \mathrm{Id} .77,478$.

95 Id. 77,478. In the court's opinion, the ANA case fell within an exception to the usual requirement of exhaustion because there were no disputed factual issues that would demand the creation of a better administrative record, and the issue involved in the case was "a pure question of law." Id. 77,463-64.

96 Id. 77,48I (Leventhal, J., concurring).

$97 \mathrm{Id}$.

$98 \mathrm{Id}$.

89 Id. 77,483 .

100 Id. Although unclear from the opinion, the term "structural flaw" appears to mean uncontested facts about agency procedures that impugn the basic fairness of the proceedings. See, for instance, Amos Treat \& Co. v. SEC, 306 F.2d 260 (D.C. Cir. 1962), in which the court of appeals held that the district court had jurisdiction to hear a claim based solely on due process grounds.

101 1980-1 Trade Cas. \63098, at 77,481-82 (emphasis added). 
agency proceeding at its core" 102 may assume jurisdiction by considering the matter "on application for a writ of mandamus . . . with jurisdiction predicated on the All-Writs Act." ${ }^{103}$ Judge Leventhal seemed to accept that this jurisdiction would be reserved for "exceptional circumstances," 104 and cautioned that "it by no means follows [from his analogy to mandamus] that a court has jurisdiction to intervene in an ongoing administrative proceeding." 105 If jurisdiction predicated on the All-Writs Act does exist, Judge Leventhal would limit such jurisdiction over Federal Trade Commission matters to the federal appellate courts. ${ }^{106}$

In the judge's judgment, judicial intervention prior to finality was not justified in Association of National Advertisers. ${ }^{107}$ The claim of bias involved in the case did not constitute a "structural flaw" because the ascertainment of bias in a person not in a position from which the probability of bias can be easily inferred would involve extensive factfinding. Such factfinding, according to Judge Leventhal, should be conducted only on review of final orders.

Judge Leventhal's theory of final agency action would limit, to a greater degree than does Judge Friendly's, the extent of judicial discretion in determining whether or not to intervene in ongoing agency proceedings. Unless a case falls within either of Judge Leventhal's exceptions, a court would lack jurisdiction over it, unable to intervene until final agency action occurs. The principal advantage of this jurisdictional approach is to reduce the number of occasions on which a court would be able to-or a litigant tempted to-circumvent the established procedures of an agency. The smooth functioning of this approach depends, however, upon a workable definition of "final action." This Comment takes up that question in part III. First, though, it is necessary to discuss further the jurisdictional interpretation of section $10(c)$.

\section{Section 10(c) as Limiting Jurisdiction}

Judge Leventhal's interpretation of section $10(\mathrm{c})$ as a limit upon the jurisdiction of the federal courts to review administrative agency actions finds little, if any support in the legislative history

$102 I d .77,482$.

103 Id.; All-Writs Act, 28 U.S.C. \$165I (1976).

104 1980-1 Trade Cas. T 63098, at 77,482 (citing Action Realty Co. v. Will, 427 F.2d 843 (7th Cir. 1970) and Green v. Murphy, 259 F.2d 591 (3d Cir. 1958)).

105 Id.

$106 \mathrm{Id}$.

107 Id. $77,483$. 
of that section. Although Congress clearly possesses the power to so restrict the jurisdiction of the courts, ${ }^{108}$ the little authority going to the point, while suggesting that the drafters of the APA regarded section 10 (c) as merely a codification of the existing law of exhaustion, is inconclusive. ${ }^{109}$ Several reasons nonetheless commend Judge Leventhal's interpretation of finality.

First, the mere fact that section 10 (c) may have codified the exhaustion doctrine alters the discretionary nature of the requirement. ${ }^{110}$ The Ninth Circuit has adopted the argument that "when exhaustion is statutorily mandated, the exhaustion requirement is jurisdictional." 111 This interpretation harmonizes well with the fact that the APA is a statute of general application, whose requirements can be avoided by the particular mandates of an agency's enabling legislation. ${ }^{112}$ Finding section 10 (c) finality a jurisdictional prerequisite, therefore, would not impose the requirement across the spectrum of administrative law. Congress could relax the requirement in particular instances.

Second, the structure of section 10(c) itself argues for a jurisdictional interpretation. The statute delineates three classes of agency action: "action made reviewable by statute," "final agency action for which there is no other adequate remedy in a court," and "preliminary, procedural, or intermediate agency action or

108 See, e.g., Fillinger v. Cleveland Soc'y for the Blind, 591 F.2d 378, 379 (6th Cir. 1979) ("Congress can make exhaustion of administrative remedies an absolute prerequisite to federal court jurisdiction."). See also City of Tacoma v. Taxpayers of Tacoma, 357 U.S. 320, 336 (1958) ("Congress, acting within its constitutional powers, may prescribe the procedures and conditions under which, and the courts in which, judicial review of administrative orders may be had.").

109 Senate Judiciary Commttee Prant (June 1945), reprinted in Administrattve Procedoure Act-Legrstattve History-79tr Cong., 1944-46, at 11, 37 (1946) [hereinafter cited as APA Ligers. Hrst.]; Letter from Tom C. Clark, Attorney General, to Hon. Pat McCarran, Chairman, Senate Judiciary Comm. (Oct. 19, 1945) (appendix), reprinted in APA LEGIs. Hist., supra, at 230; see Chrysler Corp. v. Brown, 441 U.S. 281, 302 n.31 (1979). Cf. Malone Freight Lines, Inc. v. United States, 204 F. Supp. 745, 752 (N.D. Ala. 1962) (\$10(c) of the APA "represents an effort on the part of Congress to resolve complexities of pre-existing decisional law dealing with the exhaustion problem").

110 See, e.g., Neely v. United States, 285 F.2d 438, 443 (Ct. Cl. 1961) ("Unless made a prerequisite to suit by statute, ... the extent to which a plaintiff is required to pursue his administrative remedy is a matter for the discretion of the court.") (emphasis added). See also American Dairy of Evansville, Inc. v. Bergland, 48 Ad. L.2d 197, 212, 218-25 (D.C. Cir. 1980) (Robinson, J., dissenting) (arguing that incorporation of exhaustion doctrine in $\$ 8(15)(A)$ of the Agricultural Marketing Agreement Act made exhaustion a jurisdictional prerequisite).

111 Eluska v. Andrus, 587 F.2d 996, 999 (9th Cir. 1978). See Montgomery v. Rumsfield, 572 F.2d 250, 252-53 (9th Cir. 1978). See generally Fuchs, supra note 1, at 867; Comment, Exhaustion of Administrative Remedies as a Prerequisite to Judicial Review, 44 Mrcr. L. Rev. 1035, 1041-42 (1946).

112 Attorney General's Manual on the Administrative Procedure Act 93 (1947). 
ruling[s] not directly reviewable." 113 Only the first two classes of action are "subject to judicial review." 114 It follows, therefore, that any actions not final or otherwise reviewable by statute are simply not reviewable. That is, the courts have no jurisdiction over nonfinal cases. It makes no sense to draft a statute categorizing agency action in terms of reviewability without implicitly denying jurisdiction over actions termed "not directly reviewable." Furthermore, the last sentence of section 10(c), shifting agency actions that would be final but for the possibility of further intraagency appeal or reconsideration to a reviewable status, ${ }^{115}$ makes sense only if nonfinal actions are not reviewable by the courts.

Third, the Supreme Court has flatly stated that an agency action "is subject to judicial review . . only if the [action] . . . was 'final agency action' or otherwise was 'directly reviewable' under $\S 10$ (c) of the APA." 116 This can mean only that finality is a jurisdictional prerequisite to judicial review. Although the Supreme Court has also held that section $10(c)$ does not grant the federal courts an independent ground for assuming subject matter jurisdiction, ${ }^{117}$ whether section 10 (c) can validly restrict federal court jurisdiction is a different question. Even though an agency action may be final, a court must find an independent ground for jurisdiction, such as section 1331 of title 28.118 Section 10 (c) purports only to prevent a premature assumption of jurisdiction.

A jurisdictional interpretation of section $10(c)$-absolutely barring judicial review absent a finding of finality-seems, therefore, to be justified by logic and by recent holdings of the Supreme Court. Additionally, such an interpretation has the advantage of providing a relatively clear-cut threshold requirement for judicial review, thereby forestalling potentially abusive intervention.

\section{III. "Final Agency Action" Under the APA}

\section{A. Focusing on Effects}

The preceding section attempted to establish that section 10 (c) of the APA is properly read as a limitation upon a federal court's

1135 U.S.C. $\$ 704$ (1976).

114 Id.

$115 \mathrm{Id}$.

116 FTC v. Standard Oil Co., 49 U.S.L.W. 4054, 4055 (U.S. Dec. 16, 1980) (No. 79-900) (emphasis added) (citation omitted).

117 Califano v. Sanders, 430 U.S. 99 (1977).

11828 U.S.C. $\$ 1331$ (1976) (granting federal-question jurisdiction to federal district cotrrts). 
jurisdiction to review administrative agency action. This limitation removes a court's discretion to review unless the agency action is otherwise reviewable by statute or constitutes final action for which no other remedy is available. ${ }^{119}$ The crucial question, then, becomes how to define when an agency action has become final within the meaning of section $10(\mathrm{c})$. The ensuing discussion proposes a partial theory for defining "final agency action" in a manner that will comport with the need to preserve the integrity of the administrative process and still allow the courts jurisdiction to review agency action in appropriate cases.

The term "agency action" is defined in the APA as "the whole or part of an agency rule, order, license, sanction, relief, or the equivalent or denial thereof, or failure to act." 120 "Finality," however, finds no similar definition, although it is ultimately the most critical term. For if "finality" under section 10(c) entails a large element of judicial discretion or provides courts with no clear standard to apply, the failings of the exhaustion doctrine will survive a transition to a finality analysis. The courts' jurisdiction to review would simply depend upon ad hoc determinations of whether an action is "final."

The legislative history of section 10 (c) supports a narrow construction of the term "final agency action" and suggests how to interpret it in practice. The Senate report to the Act states that "[f]inal action includes any effective agency action for which there is no other adequate remedy in any court." 121 The House report also speaks of final agency action, describing it as "effective or operative." ${ }^{122}$ Although neither report further clarifies when an agency action is final, the apparent focus is upon the effects or results of agency action. In other words, the nature of an actionwhether it is final or not- is determined in light of the nature of the effects of that action. The difficulty is that virtually any action taken by an agency will in some sense have effects, but not all actions, of course, can be final. So "effective or operative" action, to be final, must have results that are somehow different from the

1195 U.S.C. $\$ 704$ (1976). For full text of $\$ 10(\mathrm{c})$, see text accompanying note 65 supra.

120 Administrative Procedure Act, $\S 2(\mathrm{~g}), 5$ U.S.C. $\$ 551(13)$ (1976) (emphasis added).

121 S. Rep. No. 752, 79th Cong., 1st Sess. (1945), reprinted in APA Legis. Hrst., supra note 109, at 213 (emphasis added).

122 H.R. REP. No. 1980, 79th Cong., 2d Sess. (1946), reprinted in APA LEGrs. Hist., supra note 109, at 277. 
effects of nonfinal agency action. The articulation of that difference is the crux of any finality analysis.

Some light is cast by a progenitor of section $10(\mathrm{c})$, section 311 (d) of a model bill proposed by a minority report from the Attorney General's Committee on Administrative Procedure. This model bill proposed that: "Administrative orders, declaratory or otherwise, directing action, assessing penalties, prohibiting conduct, or denying claimed rights, privileges or benefits under the Constitution or statutes shall be subject to . . [ [judicial] review." ${ }^{123}$ The concern seemed to be that parties should be free to seek review of actions that have some immediate, legal effects that are external to the administrative proceeding itself. That is, review was to be permitted only when the challenged action had some demonstrable impact upon the parties that was not simply procedural or agency housekeeping.

In Pepsico, Inc. v. FTC, Judge Friendly formulated the issue thus:

The real question is under what circumstances a court should review an order which, in Mr. Justice Brandeis' famous phrase, "does not command the [party] . . . to do, or to refrain from doing any thing; which does not grant or withhold any authority, privilege, abridge any power or facility; which does not subject the [party] . . . to any liability, civil or criminal; which does not change the [party's] . . existing or future status or condition; which does not determine any right or obligation." 124

And in a recent decision of the Second Circuit, Environmental Defense Fund, Inc. v. Johnson, ${ }^{125}$ the court said that "the finality requirement [under section $10(\mathrm{c})$ ] is to be interpreted in 'a prag-

123 Final Report of the Atrorney General's Commtttee on AdMinistratrve Procedure 246 (1942). The remainder of the proposed subsection reads much like what ultimately was enacted as section $10(\mathrm{c})$ :

Provided, however, That only final orders, or orders for which there is no other adequate judicial remedy, shall be subject to such review. Preliminary or intermediate orders, so far as the same are by law reviewable, shall be subject to review upon the review of final orders. An order shall be final for purposes of such review notwithstanding that no petition for rehearing or reconsideration has been presented to the administrative authority involved.

Id.

124472 F.2d 179, 186 n.7 (2d Cir. 1972) (quoting United States v. Los Angeles \& S.L.R.R., 273 U.S. 299, 309-10 (1927)), cert. denied, 414 U.S. 876 (1973).

125629 F.2d 239 (2d Cir. 1980). 
matic way," 126 and that "in determining finality we must decide 'whether the process of administrative decisionmaking has reached a stage where judicial review will not disrupt the orderly process of adjudication and whether rights or obligations have been determined or legal consequences flow from the agency action." "127 Under this rule, the court of appeals refused to find that the "issuance of a report recommending a further study of [a New York water project could] . . possibly be characterized as a "final agency action' within the meaning of section 10 (c) of the APA." 128 Specifically, the report did "not recommend the construction of the [project] ...., nor [did] it advocate any other definitive action with respect to the project." 129 Evidently, the report in question did not have enough impact upon conditions outside the administrative process to be classified as final action. Again, the finality analysis centered on the effects of the challenged action.

In an even more recent decision, FTC v. Standard Oil Company of California (Socal), ${ }^{130}$ the Supreme Court held that "[b]ecause the [FTC]'s issuance of a complaint averring reason to believe that Socal has violated the [Federal Trade Commission] Act is not 'final agency action' under $\S 10$ (c) of the APA, it is not judicially reviewable before administrative adjudication concludes." 131 In so holding, the Court enunciated the factors that determine when an agency action becomes final by referring to its opinion in Abbott Laboratories v. Gardner. ${ }^{132}$ In Abbott, the publication by the Commissioner of Food and Drugs of regulations that required drug manufacturers to include certain information on labels and advertisements was held to be reviewable final agency action. But the Socal Court distinguished Abbott on the facts, finding that the FTC's complaint had "had no legal force or practical effect upon Socal's daily business other than the disruptions that accompany any major litigation." ${ }^{133}$ Abbott, in contrast, involved regulations that "were 'definitive' statements of the Commission's position, ... . and [that] had a 'direct and im-

126 Id. 241 (quoting Abbott Laboratories v. Gardner, 387 U.S. 136, 149 (1967)).

127 Id. (quoting Port of Boston Marine Terminal Ass'n v. Rederiaktierbolaget Transatlantic, 400 U.S. 62, 71 (1970) (emphasis added).

$128 I d$.

129 Id.

130 FTC v. Standard Oil Company of California, 49 U.S.I.W. 4054 (U.S. Dec.

15, 1980) (No. 79-900).

131 Id. 4057 (footnote omitted).

132387 U.S. 136 (1967).

133 Socal, 49 U.S.L.W. at 4056 . 
mediate *** effect on the day-to-day business' of the complaining parties." 134 The complaint in Socal, however, "[served] only to initiate the proceedings," said the Court. ${ }^{135}$

The Court's juxtaposition of agency actions having "direct and immediate ... effects on the day-to-day business" of the litigants against those having only procedural consequences reveals a great deal about the fundamental concerns of any finality analysis. Apparently, the Court wishes to prevent intervention into those agency actions having effects internal to the administrative process-such as procedural decisions-while reserving intervention for those occasions when the action impacts upon matters external to the process. The rationale for so limiting judicial intervention bears a close resemblance to the reasons articulated in McKart $v$. United States $^{136}$ for requiring exhaustion. ${ }^{137}$ But as the Court itself noted, ${ }^{138}$ exhaustion and finality are not strictly congruent; rather, the two rules serve the same end by different means.

The next section of the Comment will attempt to formulate a theory, deriving from the factors just discussed, that defines finality in a manner that will be truer to the interest of administrative independence than the exhaustion doctrine has proven to be.

\section{B. A Theory of Finality}

Although incapable of absolutely unambiguous definition, finality appears to occur when the effects of agency action are both the direct consequence of that action and, in some sense, external to the administrative process. Admittedly, no court has expressed. the predicates for finality in precisely this way, but as the Socal decision suggests, ${ }^{139}$ a theory of finality along these lines isolates the essential factors relied upon by the courts in defining final agency action. The advantage of such a theory is that it articulates two relatively clear indicia telling the courts when to intervene in ongoing agency proceedings. In particular, the proposed theory would enable courts to make their determinations based upon relatively minor incursions into, and without substantial delays of, agency proceedings. Perhaps in most cases the decision could be made upon the pleadings.

134 Id. (citation omitted).

$135 \mathrm{Id}$.

136395 U.S. 185, 193-95 (1969).

137 See notes 9-15 supra \& accompanying text.

138 Socal, 49 U.S.L.W. at 4057.

139 See text accompanying notes 133-37 supra. 


\section{Direct and External Effects}

The direct effects of agency action, as they are defined here, are those that are the immediate and intended results of the particular proceeding from which they issue. They relate to the purpose for which the administrative proceeding was begun. "Intended" does not here refer to the subjective intent of any actor or official, but rather to the intent of the proceeding, in terms of the reasons for its having been initiated. For example, to take a simple case, rulemaking is the direct effect of a rulemaking proceeding because such a proceeding is intended to produce rules. Direct effects, however, are not necessarily the sole outcome of agency action, nor are they always related to the central purpose of the proceeding. Rather, any given proceeding may produce several different direct effects, at different stages of the proceeding, and for different reasons. The idea here is that certain effects are direct because they are what the agency was trying or was supposed to do. They are not results that were either unforeseen or unintended. And it is presumed that an agency cannot intend by its action results that it had neither power nor interest in achieving. Direct effects, however, may have the kind of impact upon parties or conditions that we wish to see reviewed.

But directness is only half the equation. In order to ensure that proceedings are interrupted only when they produce final action, another factor must be introduced. Some agency actions having direct effects nonetheless do not impact upon anything other than the course of the proceeding itself. If it is important not to disrupt the orderly progress of administrative action, then we do not want to second-guess an agency in decisions bearing only upon matters internal to the process. Reviewable actions, therefore, are those that have effects "external" to the administrative proceeding. It is precisely this kind of external effect that, to paraphrase Justice Brandeis, ${ }^{140}$ commands a party to do, or to refrain from doing, something; that grants or withholds authority; that subjects a party to any liability; that changes a party's existing or future status or condition; that determines any right or obligation. In each of these situations, a decision has been made that will impact upon someone or something other than the conduct or course of the proceeding itself. Procedural rules, for instance, relate to and impact upon the proceedings themselves. They are internal to the administrative process. Calling back an earlier example, rule- 
making is an action with external effects, for that is the very purpose of the action: to have an effect upon the world outside of the administrative process.

Directness and externality overlap in the determination of finality. Obviously, any action can have multiple effects; some direct, some not, some external, some not. By looking to both variables, however, one can determine whether a particular action is final. Under the theory proposed here, finality occurs when an action is both direct and external. If the action has effects that are its immediate and intended result and that operate upon events, conditions, persons, or things separate from the proceeding itself, then that action should be considered final under section 10 (c).

As an illustration, take the suspension by the Securities Exchange Commission of a securities broker's Regulation A exemption, ${ }^{141}$ pending further administrative proceedings. Such an action, under the foregoing analysis, would be classified as final, and therefore, subject to immediate judicial review because it has an effect that is both direct and external. The suspension of the broker's exemption is clearly the immediate and intended result of the action-that was precisely what the Commission was trying to doand it is also a result bearing on conditions outside the proceeding-it did not concern the manner in which the proceeding was conducted.

Certain other agency actions would clearly not be final under this test. A decision to hold public hearings in City $A$ as opposed to Gity $B$, for instance, would not be final..$^{142}$ Although the immediate-or direct-effect of the decision is that the hearings will take place in City $A$, those effects are internal to the agency procedure; they pertain to the way in which the agency chooses to carry out its own functions. The same conclusion-that the action is not final-would obtain even if an effect of the location decision were to inconvenience greatly certain parties to the proceeding. In that case, although that effect might be considered external to the proceeding-in that it impacts upon matters outside the agency-

141 See 17 C.F.R. $\$ \$ 230.251-.264$ (Regulation A). Section 230.252 exempts certain securities from certain registration requirements under the federal securities laws. Section 230.261 provides for the suspension of this exemption under certain circumstances.

142 See, e.g., Eastern Utilities Assocs. v. SEC, 162 F.2d 385 (1st Cir. 1947) (holding in the course of affirmance of dismissal of plaintiff's petition to review an SEC order denying his motion to hold an agency proceeding in Boston instead of Philadelphia that preliminary or procedural orders of an administrative body are not directly subject to judicial review). 
that effect was not the immediate and intended result of the agency action. Such effects are merely ancillary or indirect consequences of the primary purpose of the action.

Virtually every agency action can be analyzed in this way. Any agency action can be classified as having results that are either direct and external, direct and internal, indirect (or ancillary) and external, and/or indirect (or ancillary) and internal. Only the first type of action will warrant immediate judicial review. Only that type of action will enable a court to find finality and assume jurisdiction.

Any particular action may have several types of effects. But, accepting the preceding analysis, the courts are entitled to assume jurisdiction over a case only when one or more of the effects can be classified as direct and external. Once having assumed jurisdiction over a case, however, a court cannot be denied the opportunity to examine every other issue in the case. ${ }^{143}$ The analysis offered here acts merely as a threshold requirement to a finding of jurisdiction to review an ongoing proceeding. Of course, the courts will still retain the discretionary power, under the exhaustion doctrine, to refuse to hear a case over which it has jurisdiction.

To recapitulate, the analysis presented here focuses upon the effects of agency action in determining finality. If any of the effects of a particular action are both direct and external, then the action is final. If it is final, the court may assume jurisdiction, even though the proceeding as such has not concluded. Conversely, if the challenged action has no effects that are both direct and external, then the action is not final and review must be denied for lack of jurisdiction.

The advantage of this scheme is that it substantially reduces the judicial discretion inherent in the exhaustion doctrine by creating relatively definite and objective indicia for determining when an agency has made a final action. At the same time, it frees the courts to review agency actions that might have untoward and irremediable effects upon matters in the "outside world." By reducing discretion and providing clarity, a finality approach should have the additional salutary effect of discouraging attempts to bypass agency procedures for the perceived more sympathetic judicial forum.

I43 Section 10(c) itself states that "[a] preliminary, procedural, or intermediate agency action or ruling not directly reviewable is subject to review on review of the final agency action." See also Fay v. Douds, 172 F.2d 720, 723 (2d Cir. 1949); notes 32 \& 33 supra \& accompanying text. 


\section{Mandamus Jurisdiction}

The concern of section 10 (c)'s finality requirement is to prevent the disruption of ongoing agency proceedings. ${ }^{144}$ Shifting to the finality analysis described above would necessarily reduce the applicability of a number of the exceptions to the exhaustion doctrine canvassed earlier. ${ }^{145}$ Gases in which the courts may insistperhaps justifiably-on reviewing agency actions that are clearly nonfinal, however, pose a significant problem. Presumably, the courts would not have developed exceptions to the exhaustion doctrine had they not felt that some form of judicial intervention into agency proceedings is at times appropriate, and that therefore, some "play [must exist] in the joints" of the doctrine.146 Indeed, notions of the balance and separation of administrative and judicial powers comport with such exception-making. The difficulty with the exhaustion doctrine, however, has been that the exceptions threaten to swallow the rule, at least in principle. The task of this section of this Comment is to suggest how the felt need to provide flexibility can be reconciled with the relatively rigid and narrow finality requirement.

The exception introduced by Leedom $v$. Kyne, ${ }^{147}$ for example, illustrates well the desirability of retaining some opportunities for judicial review of technically nonfinal agency action. In the Leedom case, the National Labor Relations Board had, by its own admission, ignored a statutory prerequisite to a disputed certification election; the potential consequences for the complaining union of a court's refusal to accept jurisdiction would have been a loss of exclusive bargaining rights, without any other legal recourse.148

Prospects such as this may have influenced Judge Friendly, in Pepsico, Inc. v. FTC, ${ }^{149}$ to expand the notion of finality to encompass clear statutory violations despite the absence of strictly final agency action..$^{150}$ Judge Leventhal's concurrence in Association of National Advertisers $v$. FTC, ${ }^{151}$ however, suggests a more attractive alternative. Judge Leventhal predicated the court's jurisdiction

144 See notes 88, 96-107 and 125-35 supra \& accompanying texts.

145 See notes 16-62 supra \& accompanying text.

146 See note 89 supra \& accompanying text.

147 Leedom v. Kyne, 358 U.S. 184, 192 (1958).

148 Id. 184-87, 190. See note 22 supra.

149472 F.2d 179 (2d Cir. 1972), cert. denied, 414 U.S. 876 (1973).

150 See text accompanying notes 67-90 supra.

151 1980-1 Trade Cas. If 63,098, at 77,461 (D.C. Cir. 1979), cert. denied, 100 S. Ct. 301 (1980). See notes 91-107 supra \& accompanying text. 
on the All-Writs Act, ${ }^{152}$ a statute that has traditionally permitted interlocutory judicial review in "extraordinary cases." 153

According to Judge Leventhal, review of agency action under the All-Writs Act is reserved to the courts of appeals, ${ }^{154}$ but similar extraordinary power in the district courts can be found in 28 U.S.G. $\$ 1361$, granting district court jurisdiction over actions "in the nature of mandamus." 155 Such extraordinary power could be utilized by the district courts to preserve the narrow Leedom exception.

Allowing review of nonfinal action under the mandamus statute marshalls against indiscreet judicial intervention a long-standing tradition of issuing writs of mandamus only in "the most urgent cases" 156 and a stringent set of conditions that a party seeking a writ of mandamus must meet. For example, in the Second Circuit, "[ $t]$ he prerequisites to the issuance of a writ of mandamus have been stated as (I) a clear right in the plaintiff to the relief sought; (2) a plainly defined and peremptory duty on the defendant's part to do the act in question; and (3) lack of another available, adequate remedy." 157 These conditions, carried over from the original writ of mandamus, uniformly attach in all circuits to the availability of relief under section $1361 . .^{158}$ The obstacles to invoking

15228 U.S.C. $\$ 1651$ (1976). This section provides:

(a) The Supreme Court and all courts established by Act of Congress may issue all writs necessary or appropriate in aid of their respective jurisdictions and agreeable to the usages and principles of law.

(b) An alternative writ or rule nisi may be issued by a justice or judge of a court which has jurisdiction.

153 1980-1 Trade Cas. at 77,482 (Leventhal, J., concurring) (citing Mitchell v. Sirica, 502 F.2d 375, 387 (D.C. Cir.), cert. denied, 418 U.S. 955 (1974)).

154 Id.

15528 U.S.C. $\$ 1361$ (1976). It states: “The district courts shall have original jurisdiction of any action in the nature of mandamus to compel an officer or employee of the United States or any agency thereof to perform a duty owed to the plaintiff."

156 Strait v. Laird, 445 F.2d 843, 844 (9th Cir. 1971), rev'd on other grounds, 406 U.S. 341 (1972). See Ex parte Fahey, 332 U.S. 258, 260 (1947) (mandamus reserved for "really extraordinary causes").

157 Billiteri v. United States, 541 F.2d 938, 946 (2d Cir. 1976) (citing United States ex rel. Girard Trust Co. v. Helvering, 301 U.S. 540, 543-44 (1937) and Lovallo v. Froehlke, 468 F.2d 340, 343 (2d Cir. 1972), cert. denied, 411 U.S. 918 (1973)).

158 See, e.g., Haneke v. Secretary of HEW, 535 F.2d 1291 (D.C. Cir. 1976); Commonwealth of Mass. v. Connor, 248 F. Supp. 656 (D. Mass.), aff'd, 366 F.2d 778 (1st Cir. 1966); Ríchardson v. United States, 465 F.2d 844 (3d Cir. 1972), rev'd on other grounds, 418 U.S. 166 (1974); Professional \& Tech. Eng'rs Local 1 v. Williams, 389 F. Supp. 287 (E.D. Va. 1974), aff'd, 510 F.2d 966 (4th Cir. 1975); Carter v. Seamans, 411 F.2d 767 (5th Cir.), cert. denied, 397 U.S. 941 (1969); United States v. Battisti, 486 F.2d 961 (6th Cir. 1973); Save the Dunes Council v. Alexander, 584 F.2d 158 (7th Cir. 1978); In re Cessna Distributorship Antitrust Litigation, 532 F.2d 64 (8th Cir. 1976); Ellis v. Naval Air Rework 
jurisdiction under section 1361 are thus sufficiently high that few exceptions to finality will be allowed by the section. ${ }^{159}$

Section 1361 jurisdiction would have been appropriate in Leedom: a nondiscretionary statutory duty owed to the complainant union had been breached and the union had no alternative remedy. Similarly, an agency's violation of a statutory duty to act "within a reasonable time," although not constituting final action, ${ }^{160}$ would be reviewable under section 1361. The "futility" exception ${ }^{161}$ to the exhaustion doctrine would also be an exception to finality when the conditions upon mandamus are met. The same holds for the extremely narrow international-questions exception. ${ }^{162}$

Some other exceptions to the exhaustion doctrine, however, would not survive the transition to finality. It is not enough under section 1361, for instance, to present a colorable constitutional claim. Even under the "substantial showing" requirement," ${ }^{163} \mathrm{sec}$ tion 1361 further requires that no other remedy be available. A due process claim against agency proceedings, cognizable upon some final agency action, would, therefore, not be reviewable before finality. In addition, the legal questions exception ${ }^{164}$ would in most cases probably be inapplicable owing either to the availability of adequate administrative remedies or to the adequacy of judicial review at a later stage.

The advantage of recognizing exceptions to finality only insofar as they are cognizable under section 1361 is that the jurisdictional intexpretation of section $10(\mathrm{c})$ is left tightly constrained and easily applicable, and that discretionary judicial action is subject to the tempering influences of the mandamus doctrine. As a consequence of the reduction of judicial discretion to intervene in ongoing agency proceedings, the number of cases in which parties

Facility, 404 F. Supp. 377 (N.D. Cal. 1975); Schulke v. United States, 544 F.2d 433 (10th Cir. 1976). See also Kerr v. United States District Court, 426 U.S. 394 (1976) (identical constraints on mandamus from courts of appeals to district courts).

159 For a general discussion of the $\$ 1361$ remedy and support for a narrow

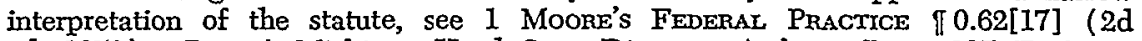
ed. 1979). But cf. Michigan Head Start Directors Ass'n v. Butz, 397 F. Supp. 1124 (W.D. Mich. 1975) (legislative history shows that Congress intended to enlarge scope of mandamus in enacting $\$ 1361$ ); Kelly v. Metropolitan County Board of Educ., 372 F. Supp. 528 (D. Tenn. 1973) (same).

160 See, e.g., Blankenship v. Secretary of HEW, 587 F.2d 329 (6th Cir. 1978);

Deering Milliken, Inc. v. Johnston, 295 F.2d 856, 865 (4th Cir. 1961).

161 See notes $42-44$ supra \& accompanying text.

162 See notes 45-48 supra \& accompanying text.

163 See text accompanying notes $32-41$ supra.

164 See notes 49 \& 50 supra \& accompanying text. 
to agency proceedings seek to skirt administrative procedures and invoke the district courts' jurisdiction should decline. ${ }^{165}$ Finally, this narrow approach to the determination of finality appears to be consistent with both the legislative history and language of section $10(c)$.

\section{CONCLUSION}

The doctrine of exhaustion of administrative remedies-longfavored as a means of preventing undue judicial interference with the administrative process-has evolved to the point at which it can no longer satisfy the purposes for which it was developed. Its many ambiguous and amorphous exceptions threaten to undermine the efficacy and authority of administrative agencies, if not by outright judicial reversals, then by encouraging disgruntled litigants to attempt to by-pass administrative procedures. In order to prevent this erosion of administrative integrity and to stem the flow of plaintiffs seeking judicial intervention, this Comment has proposed using section 10(c) of the Administrative Procedure Act as a bar against district court jurisdiction when an agency has not taken "final action." Final action, according to the proposed analysis, would occur only in those instances when an agency's action has both direct and external effects. A preliminary theory, explaining the concept of direct and external effects, has been offered, with the suggestion that flexibility be introduced into such a scheme through the use of the section 1361 jurisdiction of the federal district courts. The adoption of such an approach, it has been argued, would substantially prevent the abuses to which the exhaustion doctrine has been subject.

165 "The retention of discretion in the application of the [exhaustion] rule constitutes a continuing invitation to litigation. It is this factor, more than any other, which has resulted in an incrustation of case-law . ..." Berger, supra note 1 , at 1006. 